\title{
Old wine in new bottles
}

\author{
Glenn Branch
}

\begin{abstract}
Jeffrey P. Moran's American Genesis examines the Scopes trial in particular and the antievolution movement in general through the prisms of gender, region, and race. The diversification, of both ideology and strategy, of antievolutionism and the current impact of antievolutionism on scientists in academia are also discussed. Overall, despite a few problems, American Genesis deserves a place on anyone's list of the top 10 books on the Scopes trial and the antievolution impulse in America.
\end{abstract}

Keywords: Creationism; Scopes trial; Creation science; Intelligent design

American Genesis: The Evolution Controversies from Scopes to Creation Science. Jeffrey P. Moran. New York: Oxford University Press, 2012. Pp. 216. h/c \$29.95.

Even in the wake of Edward J. Larson's magisterial Pulitzer-prize-winning history Summer for the Gods (Larson 1997), it is still possible to contribute to the understanding of the Scopes trial. For example, Charles A. Israel's Before Scopes (2004) examined the interplay between education and religion in Tennessee in the half century leading up to 1925; Michael Lienesch's In the Beginning (2007) applied social movement theory to understand the genesis of the antievolution movement; Marcel Chotkowski LaFollette's Reframing Scopes (2008) described the role of journalists in forming the public's reaction to the trial; Adam Laats's Fundamentalism and Education in the Scopes Era (2010) situated the trial within the broad context of fundamentalist educational activism; and Adam R. Shapiro's Trying Biology (2013) emphasized the role of the textbook industry.

Unlike Summer for the Gods, however, these studies all excellent - are intended for a primarily academic audience. Is there anything new and interesting to say about the Scopes trial and its continuing aftermath for a general readership? Jeffrey P. Moran's American Genesis answers the question with a resounding yes. Marking his territory in the preface, Moran explains, 'while most works on the subject tend to focus on courtroom battles or the relation of science and faith, this book broadens the inquiry to

Correspondence: branch@ncse.com

National Center for Science Education, PO Box 9477, Berkeley, CA 94709-0477, USA argue that social forces such as gender, region, and race have intersected with the antievolution impulse in ways that shed light on modern American culture' (p. x). Gender, region, and race: these are topics that, unlike the minutiae of the textbook industry and the intricacies of social movement theory, are bound to appeal to the general reader.

Moran's approach in American Genesis was prefigured in his casebook The Scopes Trial (2002), which belongs on the bookshelf of anyone with even a passing interest in the trial. The book contains a generous sampling from the transcript from Tennessee v. Scopes, accompanied with day-by-day press reports and commentary, as well as a variety of mainly contemporary documents - including seven newspaper cartoons - on social issues relevant to the Scopes trial, such as race and gender. Moreover, Moran's clear and detailed introductory essay in The Scopes Trial devotes sections to region and ruralism in the antievolution conflict, race and evolution, and women and gender in the Scopes trial. American Genesis expands on these sections, and also devotes a chapter each to the diversification, of both ideology and strategy, of antievolutionism and to the current impact of antievolutionism on scientists in academia.

First, however, the book begins with a brief history of the relationships between science and religion, proceeding at a breakneck pace from traditional cosmologies and the glimmerings of science with the pre-Socratic philosophers through the medieval era and the Scientific Revolution to William Paley's natural theology, Darwin's life and work, and the reception of evolution in Britain and America. Slowing, Moran then offers a sensitive

\section{每 Springer}

C 2013 Branch; licensee Springer. This is an Open Access article distributed under the terms of the Creative Commons. Attribution License (http://creativecommons.org/licenses/by/2.0), which permits unrestricted use, distribution, and reproduction in any medium, provided the original work is properly cited. 
and sensible diagnosis of why antievolutionism is a distinctively (if not uniquely: see Branch 2008) American phenomenon: 'in the United States, the particular direction that antievolution controversies have taken has been determined by three major cultural characteristics: the dominance of Protestantism, the traditions of democracy, and the unique cultural diversity of the nation' (p. 17).

Chapter 1, 'Monkeys and Mothers', addresses gender in antievolutionism. Traditionally, women were responsible for the education, especially in faith and morals, of their children. Thus it was common for antievolutionists of the Scopes era to appeal to motherhood: John W. Butler, who introduced the law under which Scopes was prosecuted, explained his motivation by saying, 'As a little boy I was taught by my mother to believe in the Bible' (quoted on p. 28). And women, at least in Tennessee, were eager for the public schools to become involved in teaching faith and morals. Yet women were not leaders in the antievolutionist movement, in part, because it was driven by a selfconsciously combative, intellectualized, masculine form of Christianity: female antievolutionist crusaders like Aimee Semple McPherson were, and are, unusual.

Chapter 2, 'Regionalism and the Antievolution Impulse', addresses the tensions between the traditionalist South and the modernizing North, which the Scopes trial 'exposed and exacerbated'. Ironically, fundamentalism was initially a Northern phenomenon: a reaction to modernizing tendencies in religion that were initially influential only in the urban North. But it was adapted to flourish in the South. Moran plausibly credits J. Frank Norris, who memorably denounced 'that hell-born, Bibledestroying, deity-of-Christ-denying, German rationalism known as evolution' (de Camp 1968, p. 33), for the importation. Even today, antievolution sentiment is highest in the South and Midwest. Controversies over the teaching of evolution are apt to erupt in newly heterogeneous communities, where city and country or North and South are meeting.

Chapter 3, 'Fighting for the Future of the Race', addresses the issue of race. The Scopes trial divided the African American community. Devout African Americans declared their fidelity to the Bible, and even to fundamentalism, although the presence of established denominations and the absence of modernist theology hindered the spread of organized fundamentalism in the African American community. African American intelligentsia such as W. E. B. DuBois, however, took the side of evolution, regarding it as representing progress, both in general and for their race. They did so even though scientific racism was alive and well in $1925^{1}$; in part because they saw that scientific racism was on the wane, and in part because they were convinced that antievolutionism in the South was driven by a fear of evolution's implications with regard to race.
Chapter 4, 'Descent with Modification', addresses the diversification of antievolutionism. Moran identifies the importance of Jesus, the centrality of humanity, and the fear of social disorder as 'the three major components of the antievolution impulse' (p. 91), and traces them as they wax and wane through the course of the 90 years after the Scopes trial. The usual landmarks appear: the publication of The Genesis Flood (Morris and Whitcomb 1961), launching young-earth creationism on its rise; the decision in Epperson v. Arkansas (1968), leading to a round of creationist legislation overturned in McLean $v$. Arkansas (1982) and Edwards v. Aguillard (1987); and the post-Edwards developments of the rise of intelligent design ('less a science than a strategy', Moran shrewdly observes [p. 110]) and the inward turn of young-earth creationism.

Finally, chapter 5, 'Creationism and the Campus', addresses the reactions of modern academic scientists to antievolutionism. Although the vast majority of scientists who work on evolution are unconcerned with antievolutionism, Moran understandably highlights a few who are particularly engaged: Denis Lamoureux, who memorably debated the godfather of intelligent design, Phillip Johnson, at length (Johnson and Lamoureux 1999); Howard Van Till, whose struggles with creationists at Calvin College are discussed in detail; Kenneth R. Miller, who testified for the plaintiffs in Kitzmiller v. Dover, the 2005 trial in which teaching intelligent design in the public schools was found to be unconstitutional. The book concludes with a discussion of the National Center for Science Education's work ${ }^{2}$ and of advocacy, for and against evolution, taking place on the Internet.

Throughout American Genesis, Moran's writing is clear and fluent, and occasionally tinged with a pleasing irony. (For example, in the wake of the Scopes trial, he writes, the antievolution impulse 'continued to be associated with feminine values and occasionally with actual women' [p. 41].) His quotations and examples are chosen for effect, and while it was perhaps unnecessary for him to relate that the site of the Huxley/Wilberforce debate, the Oxford Museum, was built with the profits from Oxford University Press's sales of Bibles (p. 14), or that Marie Curie denounced the Scopes trial (p. 23), or that a sister of Scopes's lost a teaching job over her refusal to disavow evolution (p. 81), the book is surely the richer for it ${ }^{3}$. Moreover, each chapter is organized clearly, although there is no narrative or argumentive thread unifying the chapters.

As for accuracy and completeness, chapters 1 through 3 are in general satisfactory, although there are a few omissions of note. In chapter 1, although Moran mentions in passing the antievolution movement's distaste for women's suffrage, he neglects the complex role that evolution played in the women's suffrage movement in the United States (see, for example, Hamlin 2007). In 
chapter 2, his argument that antievolution incidents are still likelier to succeed in the South uses tendentious data, ignoring, for example, Ohio's flirtation with 'critical analysis' from 2002 to 2006 (Branch 2006). In chapter 3, while offering a judicious assessment of the claim that antievolutionism was driven by racism, he overlooks the fact that inerrantism is often taken to justify not only antievolutionism but also racism, through the so-called Curse of Ham (Genesis 9:20-27).

Moran cites poll data in claiming that women, Southerners, and African Americans are more likely to reject evolution than are men, Northeasterners, and the general population, respectively (pp. 44, 68, 90). Although these are robust results, reliably repeated from poll to poll, it would have been useful for him to treat them with a greater degree of statistical sophistication. There is reason to think that education, religious intensity, and religious ideology have a greater influence than gender, region, and race on acceptance of evolution. Controlling for education and religion, gender and region still have a measurable influence, but the effect of race is not statistically significant - although a separate analysis shows that education and religious ideology have a lesser influence on acceptance of evolution among African Americans than among white Americans ${ }^{4}$.

Chapters 4 and 5 attempt to cram a lot of information in a small space, and accuracy suffers on occasion, especially in chapter 4. For example, the Scofield Reference Bible is said to have popularized the day-age theory (p. 101); rather, it popularized the gap theory (Numbers 1992, pp. 45-46). Young-earth creationists are said to have 'triumphed among their compatriots in the American Scientific Affiliation' (p. 102); rather, they failed, and the Creation Research Society was founded as a result (Numbers 1992, ch. 11). The Discovery Institute is said to have retreated to the position of calling for teachers to present 'the strengths and weaknesses of evolution' by 2010 (p. 112); rather, it began that retreat around 2002, during a fight over Ohio's state science standards (Miller 2002).

Such outright errors are rare. But it was peculiar, and disappointing, not to see a discussion of the varieties of old-earth creationism, theistic evolutionism, and nonChristian forms of creationism in chapter 4 - although it is certainly true that young-earth creationism and intelligent design are the most visible forms of antievolutionism today ${ }^{5}$. Moran's discussion of the history of intelligent design starts with the publication of Phillip Johnson's Darwin on Trial (1991); while Johnson was instrumental in publicizing intelligent design, in fact, as the Kitzmiller trial revealed, intelligent design was under way even while the Edwards decision was announced. The prehistory of intelligent design remains largely uninvestigated, although Moran would have benefited from consulting a paper by Nick Matzke (2009), whom he interviewed for chapter 5 .

As in chapters 1 through 3, Moran cites poll data in chapter 4, but again not always with the utmost degree of sophistication. Citing a variety of media-driven polls that tend to show a majority of Americans supporting the inclusion of both creationism and evolution in the public schools, he comments, 'These figures suggest that antievolutionists should be able to dominate the fight' (p. 117). But a 1999 poll that offered a range of options suggested that only a minority of Americans, $29 \%$, wanted creationism taught as science People for the American Way Foundation 2000). Additionally, care needs to be taken not to take poll data on evolution too seriously: as George Bishop and his colleagues (2010) show, simply adding 'don't know' and 'not sure' as alternatives to the standard questions reveals substantial ambivalence and uncertainty in public opinion that is otherwise invisible.

Similarly, the assertion in chapter 5 that scholars and reporters 'have generally overlooked the complexities of the antievolution struggle in higher education' (p. 125) seems itself to overlook the existence of scholarly literature on the topic (including, for example, Alters and Nelson 2002), as well as abundant reports of various recent controversies involving creationists in academia, either abusing their positions to attack evolution (Forrest and Branch 2005) or complaining of discrimination, as featured in the execrable propaganda film Expelled (Frankowski 2008). Expelled, despite its status as the only creationist film to have a national release, is strangely unmentioned in American Genesis. Randy Olson's film Flock of Dodos (2006) is mentioned as a source (p. 183, n. 75), so it is not as if Moran is unaware or contemptuous of the genre.

Such nitpickery notwithstanding, American Genesis is a splendid contribution overall. A parable warns against putting new wine in old bottles. In the first three chapters of his book, however, Moran is decanting old wine the familiar events of the Scopes trial - into the new bottles of gender, region, and race. The result is still intoxicating, for the historian (who will appreciate the perceptive synthesis of a variety of sources and the intriguing hints about further avenues of research to pursue) and the general reader alike. And while the fourth and fifth chapters only scratch the surface of their topics, they are still valuable treatments, teeming with anecdote and insight. American Genesis deserves a place on anyone's list of the top 10 books on the Scopes trial and the antievolution impulse in America.

\section{Endnotes}

${ }^{1}$ Henry Fairfield Osborn of the American Museum of Natural History, for example, whose The Earth Speaks to Bryan (1925) was dedicated to Scopes, was also a virulent 
racist, writing a glowing preface to Madison Grant's The Passing of the Great Race (1916) - a book that Adolf Hitler described, in a letter to Grant, as 'my Bible'.

${ }^{2}$ Disclosure: I was interviewed by e-mail for the section of the chapter that discusses the National Center for Science Education, and quotations from me appear on pp. 149-150.

${ }^{3}$ Moran writes, 'Paducah, Kentucky, had refused to employ a mathematics teacher (who happened to be John Scopes's sister) because her opinions on evolution conflicted with the superintendent's' (p. 81). Not exactly. According to her brother, as the trial neared, Lela Scopes was asked by the Paducah board of education to deny any belief in evolution as a condition of her reappointment; when she refused, her contract was not renewed. 'She told them she did not know enough about evolution to believe or not to believe in it. She added that she would like the opportunity to study evolution and she thought everybody should have that same right' (Scopes and Presley 1967, p. 233). Scopes adds, 'Because of what they had asked her to say, she chose not to return to her old job, although contemporary reports suggest that it was the board's decision. Lela Scopes subsequently was offered and accepted a teaching job in Tarrytown, New York; the head of the school explained, 'I was impressed with the heroism of her position and decided I should like to have her on our teaching staff' (Anonymous 1925). Paducah, by the way, was their home town, and Scopes's body was buried there in 1970 .

${ }^{4}$ I thank my colleague Joshua Rosenau for analyzing the statistical information summarized here, which is based on data from the General Social Survey from 2006 to 2012 .

${ }^{5}$ The term 'creationists' is reserved by Moran 'to designate those who specifically disallow the Big Bang theory and evolution' (p. xi), that is, modern young-earth creationists; the term 'antievolutionists' is used for those who reject evolution. Such a taxonomy obscures the existence of self-described old-earth creationists, who are if anything enthusiastic about the Big Bang. It is also anachronistic, given his definition, for Moran to refer to creationists in the Scopes era (as on p. xi), since the term 'Big Bang' was not coined until the 1940s, and the idea itself, introduced (arguably) by Georges Lemaittre in 1931, was not firmly accepted within the scientific community until the 1960s.

\section{Competing interests}

The author declares that he has no competing interests.
Anonymous. (1925). Lela Scopes to teach at Tarrytown school. Middletown (NY) Daily Herald, p. 2.

Bishop, GF, Thomas, RK, \& Wood, JA. (2010). Measurement error, anomalies, and complexities in Americans' beliefs about human evolution. Survey Practice, 3(1).

Branch, G. (2006). "Critical analysis" defeated in Ohio. Reports of the National Center for Science Education, 26(3), 7-11.

Branch, G. (2008). Creationism as a global phenomenon. In RH Robbins \& MN Cohen (Eds.), Darwin and the Bible: the cultural confrontation (pp. 137-151). Boston, MA: Pearson Education.

de Camp, LS. (1968). The great monkey trial. New York: Doubleday.

Forrest, B, \& Branch, G. (2005). Wedging creationism into the academy. Academe, 91(1), 36-41.

Frankowski, N. (2008). Expelled: no intelligence allowed [film]. Santa Fe, NM: Premise Media.

Grant, M. (1916). The passing of the great race: or, the racial basis of European history. New York: Charles Scribner's Sons.

Hamlin, KA. (2007). Beyond Adam's rib: how Darwinian evolutionary theory redefined gender and influenced American feminist thought, 1870-1920 [dissertation]. Austin, TX: University of Texas.

Israel, CA. (2004). Before Scopes: evangelicalism, education, and evolution in Tennessee, 1870-1925. Athens, GA: University of Georgia Press.

Johnson, PE. (1991). Darwin on trial. Downers Grove, IL: InterVarsity.

Johnson, PE, \& Lamoureux, DO. (1999). Darwinism defeated? The JohnsonLamoureux debate on biological origins. Vancouver: Regent College Publishing.

Laats, A. (2010). Fundamentalism and education in the Scopes era: God, Darwin and the roots of America's culture wars. New York: Palgrave Macmillan.

LaFollette, MC. (2008). Reframing Scopes: journalists, scientists, and lost photographs from the trial of the century. Lawrence, KS: University Press of Kansas.

Larson, EJ. (1997). Summer for the gods: the Scopes trial and America's continuing debate over science and religion. New York: Basic Books.

Lienesch, M. (2007). In the beginning: fundamentalism, the Scopes trial, and the making of the antievolution movement. Chapel Hill, NC: University of North Carolina Press.

Matzke, N. (2009). But isn't it creationism? The beginnings of "intelligent design" and Of Pandas and People in the midst of the Arkansas and Louisiana litigation. In RT Pennock \& M Ruse (Eds.), But is it science? The philosophical question in the creation/evolution controversy, updated ed (pp. 377-413). Amherst, NY: Prometheus Books.

Miller, KR. (2002). Goodbye, Columbus. Reports of the National Center for Science Education, 22(1-2), 6-8.

Moran, JP. (2002). The Scopes trial: a brief history with documents. Boston: Bedford/ St. Martin's.

Morris, H, \& Whitcomb, JC, Jr. (1961). The Genesis flood. Philadelphia, PA: Presbyterian and Reformed.

Numbers, RL. (1992). The creationists: the evolution of scientific creationism. New York: Knopf.

Olson, R. (2006). Flock of dodos: the evolution-intelligent design circus [film]. Los Angeles: Prairie Starfish Productions.

Osborn, HF. (1925). The earth speaks to Bryan. New York: Charles Scribner's Sons.

People for the American Way Foundation. (2000). Evolution and creationism in public education: an in-depth reading of public opinion. http://www.pfaw.org/sites/ default/files/evolutionandcreationisminpubliceducation.pdf.

Scopes, JT, \& Presley, J. (1967). Center of the storm: memoirs of John T. Scopes. Holt, Rinehart and Winston. New York.

Shapiro, AR. (2013). Trying biology: the Scopes trial, textbooks, and the antievolution movement in American schools. Chicago: University of Chicago Press.

10.1186/1936-6434-6-32

Cite this article as: Branch: Old wine in new bottles. Evolution: Education and Outreach 2013, 6:32 